\title{
History Teacher Initiative Improves the Quality of Digital-Based Learning in the Covid-19 Pandemic
}

\author{
Cahyo Budi Utomo ${ }^{1, *}$ Ganda Febri Kurniawan ${ }^{2}$ Tiara Nove Ria ${ }^{3}$
}

\author{
${ }^{1}$ History Department, Faculty of Social Sciences, Universitas Negeri Semarang \\ ${ }^{2}$ History Department, Faculty of Social Sciences, Universitas Negeri Semarang \\ ${ }^{3}$ Management Department, Faculty of Economy, Universitas Pandanaran \\ *Corresponding author. Email: cahyo.bu@mail.unnes.ac.id
}

\begin{abstract}
This study aims to analyse the initiatives of history teachers in improving the quality of digital-based learning during the Pandemic. The research questions are (i) how do teachers plan history learning during the Pandemic? (ii) How do history teachers develop their learning? And (iii) what are the obstacles faced by history teachers in implementing digital-based learning? This research is a qualitative project with a survey. The research data were collected from eighteen history teachers in Semarang. Participants come from public and private schools, are divided into a balanced quantity of gender and have diverse work experiences. The results showed that learning preparation was adjusted to government recommendations and school policies during the Pandemic, activities were carried out through digital technology. Teachers use several digital applications to conduct meetings, discussions and manage assignments so that students do not get bored quickly. Constraints appear to be more visible in senior history teachers who are slow in adapting to technology. The obstacle faced by junior teachers is mastering the material and its delivery to students through the online system.
\end{abstract}

Keywords: Initiative, History Teacher, Learning, Pandemic.

\section{INTRODUCTION}

During the Covid-19 pandemic, the government has set a series of policies to maintain the quality of education and learning. Efforts that have been and are being made to improve this quality are top-down, meaning that policies and concepts are formulated and decided from the center and then implemented in schools and classrooms. Efforts to approach from above, of course, need to be balanced with bottom-up initiatives [1]-[3], In this case, the role of the teacher is essential and should be taken into account. Policies from above that have been passed down have proven to be causing many problems. First, the implementation of distance learning (DL), which is implemented freely by some schools. Second, the psychological aspect of learning, both teachers and students, weakens along with the length of time the implementation of DL. And third, the development of learning quality which is hampered by technical and theoretical problems [4]. This problem has a direct impact on learning. Until now, schools and teachers are still looking for ideal learning for an emergency.

In the Industrial Revolution 4.0, there have been many developments in the world of education [5], [6], so that teachers are required to improve their knowledge and teaching skills. The competencies possessed by teachers are proven to be able to be used dynamically in various conditions [7], [8]. Rapid technological developments make teachers have to be good at adapting and continuing to learn so that their abilities remain actual [9]. Sophisticated technology, if not supported by professional teachers, will not have a better impact. Teacher initiatives are needed in the digital learning process [10], [11], because, after all, the teacher's role as the core of teaching in the learning process cannot be replaced by technology. The history teacher is also the same, history lessons are full of stigma, and negative precedents must be changed from the thoughts and performances shown by the teacher in every lesson. 
History learning is the ideal medians to develop the character and mindsets of a society [12]-[14]. The material's content in this subject contains the journey of a nation, the reasons for the formation of a nation, and why to become a nation [15]-[17]. All of that makes this subject essential and strategic for implementing the government's interests in creating good citizenship [18]. Other subjects cannot replace the function of this subject, and history learning requires an arena of dialogue between teachers and students effectively to develop the knowledge discussed [19]. The pandemic period provides the possibility of reducing the function of history lessons. In the midst of negative sentiment towards this subject, the Pandemic situation with the DL system also allows students to be more ignorant of the learning process.

Absor [9], in his research findings, shows the weakness of history teachers in implementing DL is to ignore the affective domain. Teachers who taught initially with a textual approach became more dependent on official sources from the Government. It makes learning situations run monologue and formalistic. Amboro [4], in its findings, shows the positive impact of the Pandemic. The concept of repeated history will be contextual in certain situations. Pandemics in the past can be evocative stories in the present through the initiatives taken by teachers in planning lessons. Kurniawan [3] explained that during the initial period of the Pandemic, the learning situation became unstable, the government's indecision, and the lack of understanding of teachers in learning during an emergency made history lessons even more neglected by students. The previous researcher provided initial insight into learning history during the Pandemic, which faced many problems.

Based on the explanation above, this research has two objectives. First, reviewing history teacher initiatives in improving the quality of digital-based learning during the Pandemic. And second, analyse the learning obstacles faced. The research questions are (i) how do teachers plan history learning during the Pandemic? (ii) how do history teachers develop their learning? And (iii) what are the obstacles faced by history teachers in implementing digital-based learning? The contribution of this research lies in the idea of developing digital-based history learning in the Pandemic period, which is based on the experience of teachers.

\section{METHODS}

This research is a qualitative project with a survey [20]. The survey method was used for two reasons: the Pandemic period, which had to reduce direct contact between residents, and data collection, which was more dynamic in terms of time, making it easier for teachers to review the questions. The data of this research are verbal. The data shows the number of teachers' perception accumulation of the situation at hand and is collected through the Google form. Part of the data collection process is also carried out with focus group discussions. The research participants were eighteen history teachers from public and private schools in Semarang. Quantities in gender are divided equally in number. Work experience in school is considered in providing information. There were eleven participants with less than twenty years of service and seven participants with more than twenty years of service. The data is checked for correctness through member check [21] by making auto-clarification from participants. Data analysis applies an interactive model to create a description with sufficient and appropriate data in terms of quality or quantity [22]. Participants in the analysis of this study were grouped based on their teaching experience, namely Senior History Teachers $=$ SHT and Junior History Teachers $=$ JHT .

\section{FINDINGS}

\subsection{History teachers plan lessons during the Pandemic}

Planning for history learning during the Pandemic determines the success of learning. In the midst of changing policies, planning aspects are the keywords in carrying out their duties. With his own experience and knowledge, the history teacher tries to make his plan with ideas adapted to this particular situation. In this context, JHT appears to be more dynamic and receptive to change. JHT prepares plans according to government recommendations, from objectives, methods, media, and learning assessments following the allocation in the Pandemic situation. JHT is more skilled in operating technology and encourages students to be actively involved in digital learning through the application of various methods and media. Based on the findings, online meeting applications that are popular among teachers are; Zoom Meeting, Google Meet, WhatsApp Group, Telegram, Instagram, and MS Team.

Different things are done by SHT who have more extended work experience. SHT usually emphasizes more on the delivery of materials and assignments. More mature experience and wider mastery of material and historical themes make teachers do more of the lecture process in class. The teacher believes that discussions about historical material online or not will significantly affect students' thinking about history. Any media or method can be used and developed, but if the mastery of the material is weak, the results will not be optimal. SHT has strong beliefs about process standards in the context of information transfer. Meanwhile, JHT is more creative in adapting and utilizing technology.

The learning methods and media used tend to be more varied than the JHT. In this context, the teacher dares to apply the discovery or inquiry model to spur student learning. However, its application is still emphasized in the digital context, such as looking for biographies of 
female historical figures, Indonesian economic thinkers in history, and other figures sourced from the internet. The teacher also emphasizes the importance of collection method and filter information, for that the teacher provides recommendations for trusted websites, for example, historia.id. SHT does something different, which mainly emphasizes a one-way delivery method that emphasizes direct interaction with students. The SHT often gave reading assignments and rarely gave case studies or investigative assignments. The learning media used by SHT are simpler, such as pictures and posters. Meanwhile, JHT is more attractive by displaying videos and info graphics with more complex information.

Learning assessment between SHT and JHT is not much different. Both rely on email or social media such as Email, WhatsApp, and Telegram to collect assignments and exam results, mostly done without direct supervision. Cases of supervised exam work occur by several JHTs, namely with the Zoom Meeting or Google Meet application, then the exam is carried out at a specified time and then collected via email. The teacher will directly check the test results and identify students who do plagiarize.

\subsection{History teachers develop their learning}

The development carried out by SHT and JHT has a fundamental difference from the approach and content of development. JHT, with more actual insight and skills, can search, collect, and create relevant supporting media and teaching materials in the online learning system. For example, info graphics, short videos, and animations. The media is communicative enough for students and clarifies the meaning of the material being taught. The teacher assumes that students will be more interested in learning history and make history a priority. In addition, JHT also improvises more in a class by accessing social media such as Instagram, Facebook, Twitter, and YouTube with popular historical content. It increases the possibility of the teacher attracting the enthusiasm and activeness of students.

JHT, in practice, further develops the approach in teaching and the content of the lecture material given. The teacher tries to provide contextualization of the material by displaying relevant pictures with the help of power points. The teacher tries to convey material by textbooks and other official sources, thus spurring students to learn more about the material provided. The teacher believes that if the material is presented clearly and thoroughly, students will understand more. Development in the delivery of this material is part of what JHT emphasizes for learning with a digital system. Teachers also tend to rely on Zoom Meeting or Google Meet intensely for use in learning, but the features of these two applications have not been used optimally.

\subsection{Constraints faced by history teachers in digital-based learning}

The obstacles faced by teachers in digital learning can be drawn into two aspects: technical and theoretical. Technical constraints include the availability of tools to carry out learning. Tools in digital learning are more complex and systematic, meaning that every tool used will be connected and impactful. Such as computers, smartphones, and internet networks that cannot be separated from the three. These tools will be easy to use if the student population is a society with a high economic level, which usually lives in the city center. Meanwhile, people with moderate to low economic levels in the suburbs will be hampered because the availability of these tools is not evenly distributed. The downtown schools have easier access to the internet, while those in the suburbs have limited access. The teacher overcomes this problem by making connectivity between students, namely making students who have complete equipment into a team with incomplete equipment and adjacent houses. This model is considered adequate to cut the learning gap between the two. The teacher limits one group to only two to three students with health protocols that are still adhered to under the supervision of parents.

Theoretical constraints seem to hinder the process of teacher initiatives in improving the quality of student learning. It relates to teachers' mastery of policies, learning theories, and student study habits that need to be adjusted during the Pandemic. JHT has a significant weakness in mastering the material and reading the Government's policies or recommendations, although adjustments to the check and re-check pattern are made to produce tools that are suitable for use. While the SHT has problems adjusting the equipment to policies due to problems with mastering technology, such as making device designs and preparing media, the teachers are mature enough to transfer materials and read existing policies. In the end, the teachers are not able to follow all the recommendations given. The solution to the obstacles faced is the collaboration process between SHT and JHT which continues to be communicated intensely through WhatsApp Group and Telegram. This collaboration complements each other's shortcomings and creates a productive academic climate for both SHT and JHT.

\section{DISCUSSION}

This study begins a discussion about the history teacher's initiatives in improving the quality of learning from a history teacher's perspective directly. History teachers with more extended work experience have a high level of maturity in packaging and making learning materials. This history teacher opens the possibility for students to learn the material more fully even though they are in a pandemic. It proves Absor's [9] opinion that learning during the Pandemic emphasizes the role and 
quality of teachers to maintain the quality of learning. Teachers with professional quality have a better ability to improve the quality of learning under any circumstances. This opinion is also in line with the findings of Hussin [7] that learning in the 4.0 Industrial Revolution era cannot be separated from pedagogical basics such as teaching strategies and the ability to provide comprehensive material. Good quality of learning is realized because of the quality of teachers and teaching materials that are relevant to students. Meanwhile, teachers with shorter teaching experience stand out in technological improvisation. Adaptation to technology is fast, resulting in more attractive media, methods, and packaging of learning content. It supports Gusty et al. [2] that online learning is more dynamic for young teachers because of more mature mastery of technology. The teacher also wins the psychology of students faster because the soul of the times is not too far. It means that the pattern of initiatives between teachers with longer and shorter tenures has fundamental differences that are influenced by experience and the spirit of the times.

The history teacher's initiative in digital learning is aimed at the success of the teaching and learning process with the conditions being faced. The use of digital technology is a second step that transitions into a primary step during the Pandemic. Teachers fully understand that the teaching and learning process must change, adapting to the conditions of the times. The results of this study support the opinion of Kurniawan [3] that the online learning process in a technological adaptation pattern does not hinder the teacher's world view in teaching preparation, teaching styles, and the development of learning tools. Teachers maintain habits during face-toface learning that are in accordance with online learning patterns such as lectures and the provision of alternative reading materials. This study also supports Amboro [4] opinion that contextual history learning is part of a teaching strategy that can be developed in a pandemic situation. History teachers with different ranges of teaching experience have a point of view on the same historical contextually, which is a process of developing learning subjects by paying attention to developing situations. This kind of understanding becomes a concrete discourse produced as a primary principle in taking initiatives to maintain and improve the quality of digital-based history learning.

So, the initiatives taken by history teachers in improving the quality of learning during the Pandemic are determined by: experience and length of work as dominant factors. These two factors are supported by non-dominant factors such as: basic skills, conceptual understanding of learning, and psychological dimensions. The initiatives carried out are guided by theoretical or practical academic principles. This understanding is relevant to the needs of students in receiving information in different ways of learning. The performance of history teachers during the Pandemic reinforces the notion that a bottom-up approach is important to consider in making a policy or recommendation for learning during special conditions, so the quality of learning will be maintained and can be consistently improved with relevant pedagogical foundations.

\section{CONCLUSION}

This research focuses on analysing history teacher initiatives in digital learning during the Covid-19 pandemic. Research findings show that the pandemic situation weakens teacher creativity. It is due to unstable policies and recommendations that are difficult to adapt in certain areas. In addition, school policies, which should be more practical, still tend to be theoretical and do not provide concrete solutions. Teacher planning has been adapted to the online learning system and by government recommendations. The Zoom Meeting, Google Meet, WhatsApp Group, Telegram, Instagram, and MS Team applications are the focus and the most popular among teachers. The history teacher's obstacles in initiating quality improvement can be divided into senior and junior teachers. Senior teachers face more problems with technology adaptation, while junior teachers are constrained in the mastery of the material and its delivery which is less developed with the more limited meeting time. In conclusion, a self-actualization program is needed for senior and junior history teachers to improve the quality of learning during the Pandemic. The bottom-up approach needs to be considered by the government or schools in implementing digital-based learning policies.

\section{AUTHORS' CONTRIBUTIONS}

Articles compiled by three authors with division of tasks; The first author as the compiler of the framework of research and analysis. The second author as field data taker and adjuster of manuscript format. And the third author as a manuscript translator.

\section{ACKNOWLEDGMENTS}

The publication of research results is supported by lecturer research funding from the Universitas Negeri Semarang.

\section{REFERENCES}

[1] A. Benešová and J. Tupa, "Requirements for education and qualification of people in Industry 4.0," Procedia Manuf., vol. 11, pp. 2195-2202, 2017.

[2] S. Gusty et al., Belajar Mandiri: Pembelajaran Daring di Tengah Pandemi Covid-19. Yayasan Kita Menulis, 2020. 
[3] G. F. Kurniawan, "Problematika Pembelajaran Sejarah dengan Sistem Daring," Diakronika, vol. 20, no. 2, pp. 76-87, 2020.

[4] K. Amboro, "Kontekstualisasi Pandemi Covid-19 dalam Pembelajaran Sejarah," Yupa Hist. Stud. J., vol. 3, no. 2, pp. 90-106, 2019.

[5] D. Lase, "Education and industrial revolution 4.0," J. Handayani Pgsd Fip Unimed, vol. 10, no. 1, pp. 48-62, 2019.

[6] A. A. Shahroom and N. Hussin, "Industrial revolution 4.0 and education," Int. J. Acad. Res. Bus. Soc. Sci., vol. 8, no. 9, pp. 314-319, 2018.

[7] A. A. Hussin, "Education 4.0 made simple: Ideas for teaching," Int. J. Educ. Lit. Stud., vol. 6, no. 3, pp. 92-98, 2018.

[8] V. Puncreobutr, "Education 4.0: New challenge of learning," St Theresa J. Humanit. Soc. Sci., vol. 2, no. 2, 2016.

[9] N. F. Absor, "Pembelajaran Sejarah Abad 21: Tantangan dan Peluang dalam Menghadapi Pandemi Covid-19," CHRONOLOGIA, vol. 2, no. 1, pp. 30-35, 2020.

[10] D. Mitch, "The role of education and skill in the British industrial revolution," in The British Industrial Revolution, Routledge, 2018, pp. 241279.

[11] E. G. West, Education and the industrial revolution. Batsford London, 1975.

[12] S. H. Hasan, "Pendidikan sejarah untuk memperkuat pendidikan karakter," Paramita Hist. Stud. J., vol. 22, no. 1, 2012.

[13] G. F. Kurniawan, "Pembelajaran Sejarah di Kelas XI SMA Semesta Bilingual Boarding School Semarang," Hist. Pedagog., vol. 8, no. 1, pp. 6875, 2019.

[14] C. B. Utomo, Model-Model Pembelajaran Sejarah Yang Mengaktifkan. Semarang: UNNES Press, 2010.

[15] E. Oglesby, "Historical memory and the limits of peace education: Examining Guatemala's memory of silence and the politics of curriculum design," Teach. Violent Past Hist. Educ. Reconcil., pp. 175202, 2007.

[16] A. Osler, "Patriotism, multiculturalism and belonging: political discourse and the teaching of history," Educ. Rev., vol. 61, no. 1, pp. 85-100, 2009.

[17] S. Wineburg, Why learn history (When it's already on your phone). University of Chicago Press, 2018.

[18] R. Hallam, "Piaget and the teaching of history," Educ. Res., vol. 12, no. 1, pp. 3-12, 1969.

[19] C. Utomo and W. Wasino, "An Integrated Teaching Tolerance in Learning History of Indonesian National Movement at Higher Education," J. Soc. Stud. Educ. Res., vol. 11, no. 3, pp. 65-108, 2020.

[20] J. W. Creswell and C. N. Poth, Qualitative inquiry and research design: Choosing among five approaches. Sage publications, 2016.
[21] R. C. Bogdan and S. K. Biklen, "Qualitative research in (validation) and qualitative (inquiry) studies," It Method-Appropr. Educ. Introd. Theory Methods, 2006.

[22] M. B. Miles, A. M. Huberman, and J. Saldana, Qualitative data analysis: A methods sourcebook. Sage Publications, Inc, 2014. 